Agritech, 39 (3) 2019, 234-242

\title{
Pendekatan Perolehan Lahan sebagai Alternatif Mitigasi Banjir Surakarta
}

\author{
Land Acquisition Approach as an Alternative for Surakarta Flood Mitigation \\ Muhammad Chrisna Satriagasa ${ }^{1 *}$, Akhmad Makhfatih ${ }^{2}$ \\ ${ }^{1}$ Fakultas Kehutanan, Universitas Gadjah Mada, Jl. Agro, Bulaksumur, Yogyakarta, 55281, Indonesia \\ ${ }^{2}$ Fakultas Ekonomika dan Bisnis, Universitas Gadjah Mada, Jl. Sosio Humaniora No. 1, Bulaksumur, \\ Yogyakarta, 55281, Indonesia \\ *Email : m.chrisna.s@mail.ugm.ac.id
}

Tanggal submisi: 14 Mei 2019; Tanggal penerimaan: 20 Juni 2019

\begin{abstract}
ABSTRAK
Kota Surakarta telah mengalami berbagai kerugian akibat banjir. Sub-DAS Kali Pepe merupakan daerah aliran sungai yang berkontribusi pada banjir yang terjadi di Kota Surakarta, utamanya oleh faktor wilayah hulu yang didominasi oleh aktivitas pertanian. Pembebasan lahan di wilayah hulu Sub-DAS Kali Pepe untuk penghutanan kembali mampu mengurangi debit aliran yang mengalir ke wilayah hilir, Kota Surakarta. Tujuan penelitian ini yaitu 1) membuat delineasi wilayah pembebasan lahan, 2) menentukan besarnya nilai penggantian wajar, 3) menghitung besarnya pengurangan debit aliran. Analisis kemampuan lahan menggunakan sistem informasi geografis digunakan untuk menentukan wilayah yang akan dibebaskan. Selanjutnya nilai penggantian wajar dihitung berdasarkan Standar Penilaian Indonesia 306 dengan melibatkan komponen pengantian fisik dan penggantian non fisik. Besarnya pengurangan debit aliran Sub-DAS Kali Pepe dihitung menggunakan model debit rasional. Hasil menunjukkan bahwa hasil delineasi seluas 1.269,67 Ha yang menjadi target pembebasan lahan di hulu Sub-DAS Kali Pepe membutuhkan nilai penggantian wajar sebesar Rp. 909 miliar. Perlakukan yang dilakukan menurunkan debit aliran sebesar 139.263 It/detik atau 29,4\%. Pengurangan debit aliran yang dilakukan mampu menjadi solusi dalam mengatasi masalah banjir di wilayah hilir Sub-DAS Kali Pepe yaitu Kota Surakarta.
\end{abstract}

Kata kunci: Nilai penggantian wajar; mitigasi banjir; daerah aliran sungai

\begin{abstract}
Surakarta City has experienced various losses due to flooding. Kali Pepe Catchment contributes to flooding that occurs in Surakarta City, mainly by upstream areas dominated by agricultural activities. Land acquisition in the upstream area of Kali Pepe Catchment for reforestation can reduce the river discharge into the downstream region of Surakarta City. This study aimed at 1) making delineation of land acquisition areas, 2 ) determining the amount of fair replacement value, 3) calculating the amount of river discharge reduction. Analysis of land capability using a geographic information system was used to determine the reforestation area. The fair replacement value was calculated based on the Indonesian Assessment Standard 306, by involving the physical replacement component and non-physical replacement. The amount of river discharge reduction of the Kali Pepe Catchment was calculated using a rational discharge model. The results showed that the delineation of $1.269,67$ ha, which is the target of land acquisition in the upstream of the Kali Pepe Catchment, requires a replacement value of IDR 909 billion. This treatment reduced the river discharge by $139.263 \mathrm{It} / \mathrm{sec}$ or $29.4 \%$. River discharge reduction can be a solution in overcoming flooding problems in the downstream region of the Kali Pepe Catchment, Surakarta City.
\end{abstract}

Keywords: Fair acquisition value; flood mitigation; watershed 


\section{PENDAHULUAN}

Banjir merupakan bencana alam yang banyak terjadi di dunia (K.Waghwala \& P.G.Agnihotri, 2019; M.Millerab \& Shirzaeia, 2019; Pilla, dkk, 2019). Setiap kejadian banjir mengakibatkan berbagai macam kerugian, terutama banjir yang terjadi di perkotaan (Bahinipati, dkk, 2015; Lestari, 2002). Hal yang serupa terjadi pada Kota Surakarta bahkan telah berulangkali. Hal ini mengakibatkan gangguan aktivitas perekonomian di kota ini. Banjir yang terjadi di Kota Surakarta tidak dapat terlepas dari kondisi di wilayah hulu karena Kota Surakarta terletak pada wilayah hilir (Gambar 1). Salah satu daerah aliran sungai yang mengalir ke Kota Surakarta yaitu Sub-DAS Kali Pepe yang memiliki hulu di wilayah Kabupaten Boyolali. Peningkatan debit air di wilayah hilir disebabkan oleh alih fungsi lahan di wilayah hulu Daerah Aliran Sungai (Li dkk, 2013; Shi dkk, 2013; Liu dkk, 2014; Paul, 2016; Zhang dkk, 2016). Wilayah hulu Sub-DAS Kali Pepe digunakan untuk berbagai macam keperluan budidaya seperti pertanian dan permukiman yang kurang sesuai dengan karakteristik lahan, akibatnya akan mengakibatkan degradasi lahan dan peningkatan runoff ke wilayah hilir.

Wilayah hulu sejatinya memiliki fungsi hidrologis sebagai pengatur daur air yaitu sebagai wilayah resapan. Perubahan tutupan lahan pada wilayah ini akan mengakibatkan perubahan imbangan hidrologis sehingga berdampak pada meningkatnya runoff. Salah satu alternatif dalam pemulihan fungsi hidrologis di Sub-DAS Kali Pepe yaitu dengan cara penghutanan kembali. Beberapa wilayah yang terpilih untuk proses penghutanan kembali perlu dilakukan upaya pembebasan lahan mengingat lahan di wilayah tersebut dikuasai oleh masyarakat. Pembebasan lahan untuk membangun kembali hutan dimaksudkan untuk mengurangi runoff dari wilayah hulu sehingga akumulasi air di Kota Surakarta sebagai wilayah hilir berkurang. Tujuan dari penelitian ini yaitu 1) membuat delineasi wilayah pembebasan lahan, 2) menentukan besarnya nilai penggantian wajar, 3) menghitung besarnya pengurangan debit aliran.

\section{METODE PENELITIAN}

\section{Bahan}

Penelitian ini memerlukan beberapa bahan untuk dapat mencapai tujuan penelitian. Bahan penelitian bersama dengan perolehannya disajikan secara rinci pada Tabel 1.

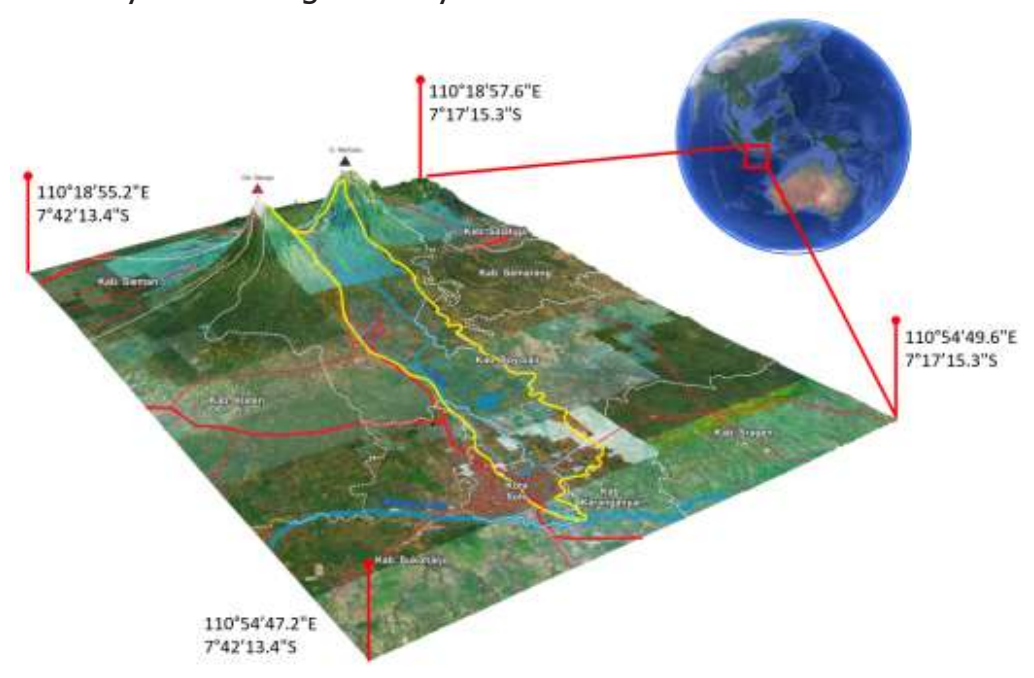

Gambar 1. Sub-DAS Kali Pepe

Tabel 1. Bahan penelitian

\begin{tabular}{cll}
\hline No. & \multicolumn{1}{c}{ Bahan } & \multicolumn{1}{c}{ Perolehan } \\
\hline 1 & Peta batas administrasi skala 1:25.000 & Ekstraksi data dari peta Rupa Bumi Indonesia \\
2 & Peta kontur elevasi skala $1: 25.000$ c.i. 12,5 m & Ekstraksi data dari peta Rupa Bumi Indonesia \\
4 & Peta jaringan sungai skala 1:25.000 & Ekstraksi data dari peta Rupa Bumi Indonesia \\
5 & Peta batas Daerah Aliran Sungai (DAS) Pepe & Pengolahan data kontur dan jaringan sungai \\
6 & Peta tutupan lahan skala 1:25.000 & Ekstraksi dari citra satelit resolusi tinggi \\
7 & Data Hujan Kabupaten Boyolali & Boyolali dalam Angka, BPS \\
\hline
\end{tabular}




\section{Metode}

\section{Penentuan wilayah pembebasan lahan}

Penentuan wilayah pembebasan lahan untuk mengurangi dampak banjir di wilayah hilir dilakukan beberapa tahapan. Tahapan pertama yaitu membuat peta satuan lahan yang disusun oleh beberapa parameter lahan yang meliputi kemiringan lereng, tekstur tanah, drainase, kedalaman tanah, erosi, dan kerawanan banjir. Keenam parameter lahan tersebut digabungkan menggunakan sistem informasi geografis sehingga menghasilkan peta satuan lahan.
Tahapan kedua, menentukan kemampuan lahan pada setiap satuan lahan. Kemampuan lahan pada SubDAS Kali Pepe terdiri dari kelas kemampuan I hingga kelas VIII pada Tabel 2 seperti yang diusulkan oleh Hardjowigeno \& Widiatmaka (2007). Sesuai dengan Tabel 2, penelitian ini mendefinisikan bahwa kelas kemampuan VI hingga VIII tidak dapat digunakan untuk aktivitas pertanian semusim sehingga merupakan target pembebasan lahan. Secara lengkap penentuan wilayah pembebasan lahan disajikan pada Gambar 2.

Tabel 2. Hubungan antara kelas kemampuan lahan dengan intensitas dan macam penggunaan

\begin{tabular}{|c|c|c|c|c|c|c|c|c|c|}
\hline \multirow[b]{2}{*}{ Kelas } & \multirow{2}{*}{$\begin{array}{l}\text { Cagar } \\
\text { alam }\end{array}$} & \multirow[b]{2}{*}{ Hutan } & \multicolumn{3}{|c|}{ Penggembalaan } & \multicolumn{4}{|c|}{ Pertanian } \\
\hline & & & Terbatas & Sedang & Intensif & Terbatas & Sedang & Intensif & $\begin{array}{l}\text { Sangat } \\
\text { intensif }\end{array}$ \\
\hline I & & & & & & & & & \\
\hline II & & & & & & & & & \\
\hline III & & & & & & & & & \\
\hline IV & & & & & & & & & \\
\hline V & & & & & & & & & \\
\hline VI & & & & & & & & & \\
\hline VII & & & & & & & & & \\
\hline VIII & & & & & & & & & \\
\hline
\end{tabular}

Sumber: Hardjowigeno dan Widiatmaka (2007)

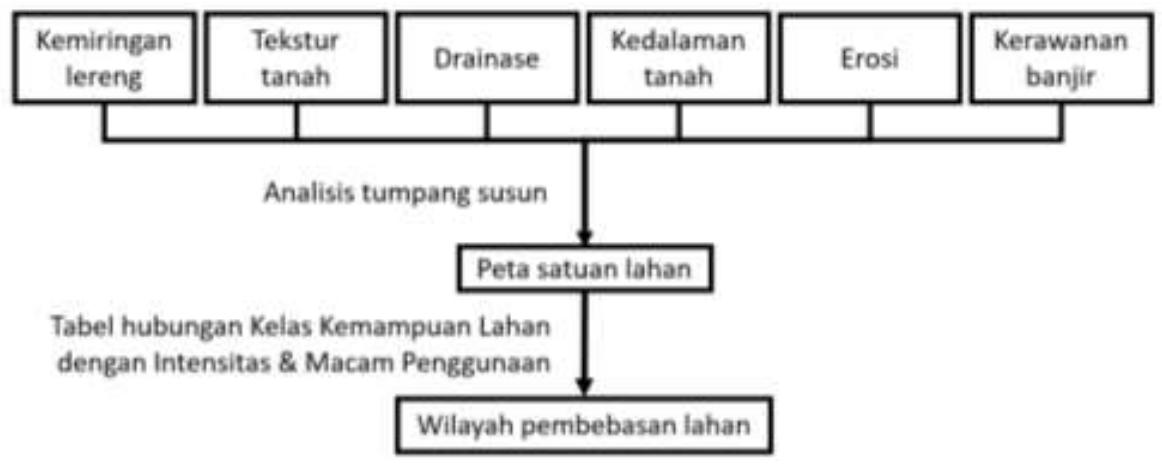

Gambar 2. Skema penentuan wilayah pembebasan lahan

\section{Penghitungan nilai penggantian wajar (NPW)}

Nilai penggantian wajar (NPW) untuk pembebasan lahan wilayah hulu Sub-DAS Kali Pepe dihitung berdasarkan beberapa dokumen yaitu:

a. Standar Penilaian Indonesia 306 (SPI 306) tentang Penilaian Terhadap Pengadaan Tanah Bagi Pembangunan untuk Kepentingan Umum (Komite Penyusunan SPI, 2015) b. Petunjuk teknis SPI 306 Penilaian Terhadap Pengadaan Tanah Bagi Pembangunan untuk Kepentingan Umum (KPSPI, 2014)

c. Undang-Undang Republik Indonesia Nomor 2 Tahun 2012 tentang Pengadaan Tanah Bagi Pembangunan untuk Kepentingan Umum (Presiden Republik Indonesia, 2012b)

d. Peraturan Pemerintah Nomor 71 Tahun 2012 tentang Penyelenggaraan Pengadaan Tanah Bagi 
Pembangunan untuk Kepentingan Umum (Presiden Republik Indonesia, 2012a)

e. Undang-Undang Nomor 5 Tahun 1960 tentang Peraturan Dasar Pokok-Pokok Agraria (Presiden Republik Indonesia, 1960)

Penghitungan NPW seperti yang disajikan dalam formula 1 terdiri dari 2 bagian yaitu nilai penggantian fisik dan nilai penggantian non fisik. Nilai penggantian fisik terdiri dari tanah atau tanah dan bangunan, bangunan dan/atau sarana pelengkap, dan tanaman. Sedangkan komponen non fisik terdiri dari solatium, biaya transaksi, kompensasi masa tunggu, kerugian sisa tanah, dan kerusakan fisik lainnya.

NPW $(R p)=$ Nilai Penggantian Fisik+Nilai Penggantian Non Fisik

\section{Penghitungan pengurangan debit aliran}

Pengurangan debit aliran merupakan konsekuensi logis dari perubahan tutupan lahan di wilayah hulu SubDAS Kali Pepe. Penelitian ini menggunakan model debit rasional dalam mengalkulasi perubahan debit aliran seperti yang disajikan dalam formula 2 .

$$
\mathrm{Q}=\mathrm{C} \times \mathrm{I} \times \mathrm{A}
$$

$$
\begin{aligned}
& \text { Keterangan Q : debit aliran permukaan I : intensitas hujan } \\
& \text { C : koefisien runoff A : luas penggunaan lahan }
\end{aligned}
$$

Penelitian ini mengasumsikan seluruh jenis tutupan lahan pada wilayah dengan kelas kemampuan VI hingga VIII diubah menjadi hutan lindung. Hal tersebut berdampak pada perubahan komponen koefisien runoff (C) yang pada akhirnya akan mengubah nilai debit aliran permukaan (Q).

\section{HASIL DAN PEMBAHASAN}

\section{Karakteristik Wilayah Kajian}

Karakteristik wilayah kajian digambarkan menggunakan 6 parameter. Keenam parameter tersebut yaitu kemiringan lereng, tekstur tanah, drainase, kedalaman tanah, erosi, dan kerawanan banjir seperti yang disajikan pada Gambar 3. Keenam parameter ini merupakan dasar pembentukan satuan lahan untuk melakukan analisis penentuan wilayah pembebasan lahan.

Wilayah kajian penelitian merupakan wilayah yang terletak di Lereng Gunungapi Merapi dan Lereng Gunung Merbabu. Sebagai wilayah yang terletak di lereng gunung, wilayah hulu dan hilir memiliki karakteristik yang berbeda satu sama lain. Wilayah hulu Sub-DAS Kali Pepe memiliki karakteristik kelas kemiringan lereng datar-curam (0-30\%) hingga berbukit-sangat curam $(30->45 \%)$, tekstur tanah agak kasar hingga kasar, drainase baik hingga agak baik, kedalaman tanah sangat dangkal hingga sedang, erosi berat hingga ringan, dan kerawanan banjir tidak pernah. Di sisi lain, wilayah hilir Sub-DAS Kali Pepe memiliki karakteristik kelas kemiringan lereng datar-berombak (0-15\%).

\section{Penentuan Wilayah Pembebasan Lahan}

Sub-DAS Kali Pepe yang memiliki luas wilayah $31.063,5 \mathrm{Ha}$ terbagi menjadi 6 kelas kemampuan lahan. Keenam kelas kemampuan lahan tersebut yaitu kelas kemampuan lahan I, III, V, VI, VII, dan VIII. Kelas kemampuan lahan I dan III berturut-turut terletak pada wilayah hilir dan tengah Sub-DAS Kali Pepe. Sedangkan kelas kemampuan lahan V, VI, VII, dan VIII terletak di wilayah hulu. Distribusi spasial kemampuan lahan di Sub-DAS Kali Pepe disajikan pada Gambar 4.

Hardjowigeno \& Widiatmaka (2007) menyebutkan bahwa kelas kemampuan lahan VI dan VII hanya dapat digunakan untuk keperluan penggembalaan dengan intensitas berturut-turut intensitas sedang dan intensitas terbatas. Selanjutnya, kelas kemampuan lahan VIII hanya dapat digunakan sebagai cagar alam atau tidak dapat digunakan sebagai lahan budidaya. Berdasarkan hal tersebut, penelitian ini mendefinisikan lahan dengan kelas kemampuan VI hingga VIII merupakan wilayah yang menjadi target pembebasan lahan.

\section{Penghitungan Nilai Penggantian Wajar}

Wilayah target pembebasan lahan yang ditentukan memiliki luasan 1.269,67 Ha. Luasan tersebut meliputi 3 kecamatan dan 9 desa di Kabupaten Boyolali. Jenis tutupan lahan yang terlingkup dalam luasan tersebut terdiri dari 3 tipe, yaitu hutan, tanah bangunan, dan tanah pertanian. Secara rinci luasan jenis penggunaan tiap desa disajikan pada Gambar 5.

Perhitungan nilai penggantian fisik terdiri dari komponen tanah bangunan, tanah pertanian, bangunan dan sarana pelengkap, tanaman pertanian, dan tanaman keras. Total nilai penggantian fisik berjumlah Rp615,3 miliar yang dirinci pada Tabel 3. Penggantian tanah pertanian memiliki kontribusi terbesar dibandingkan komponen lainnya yaitu $65,6 \%$. Hal ini wajar karena sebagian besar wilayah target pembebasan lahan di hulu Sub-DAS Kali Pepe digunakan sebagai lahan pertanian tanaman semusim.

Nilai penggantian wajar tidak hanya meliputi komponen nilai penggantian fisik, tetapi juga nilai penggantian non-fisik. Hal ini ditegaskan oleh Irawan \& Paranata (2010) bahwa aset non-fisik perlu untuk diperhitungkan selain penggantian aspek fisik. Nilai 


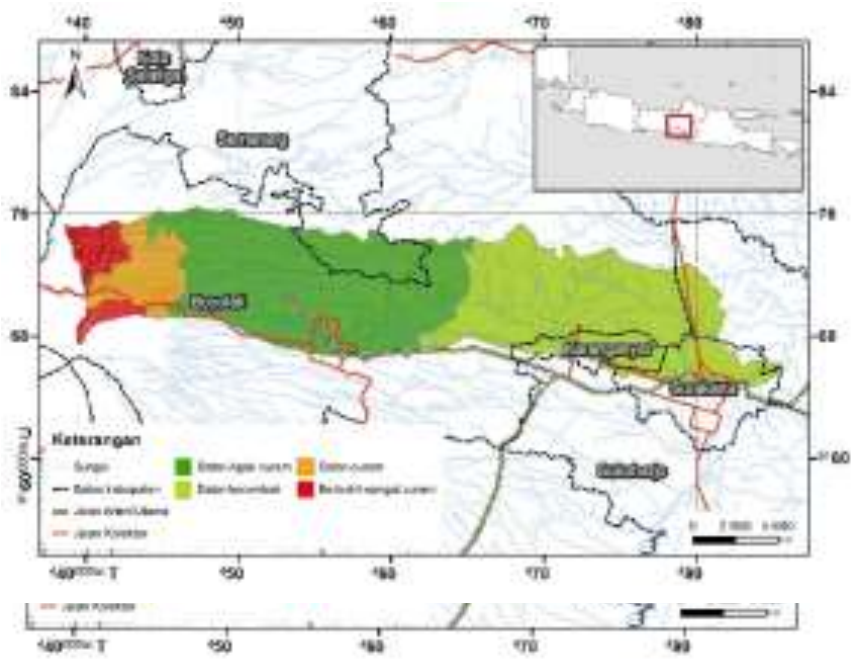

Kemiringan lereng
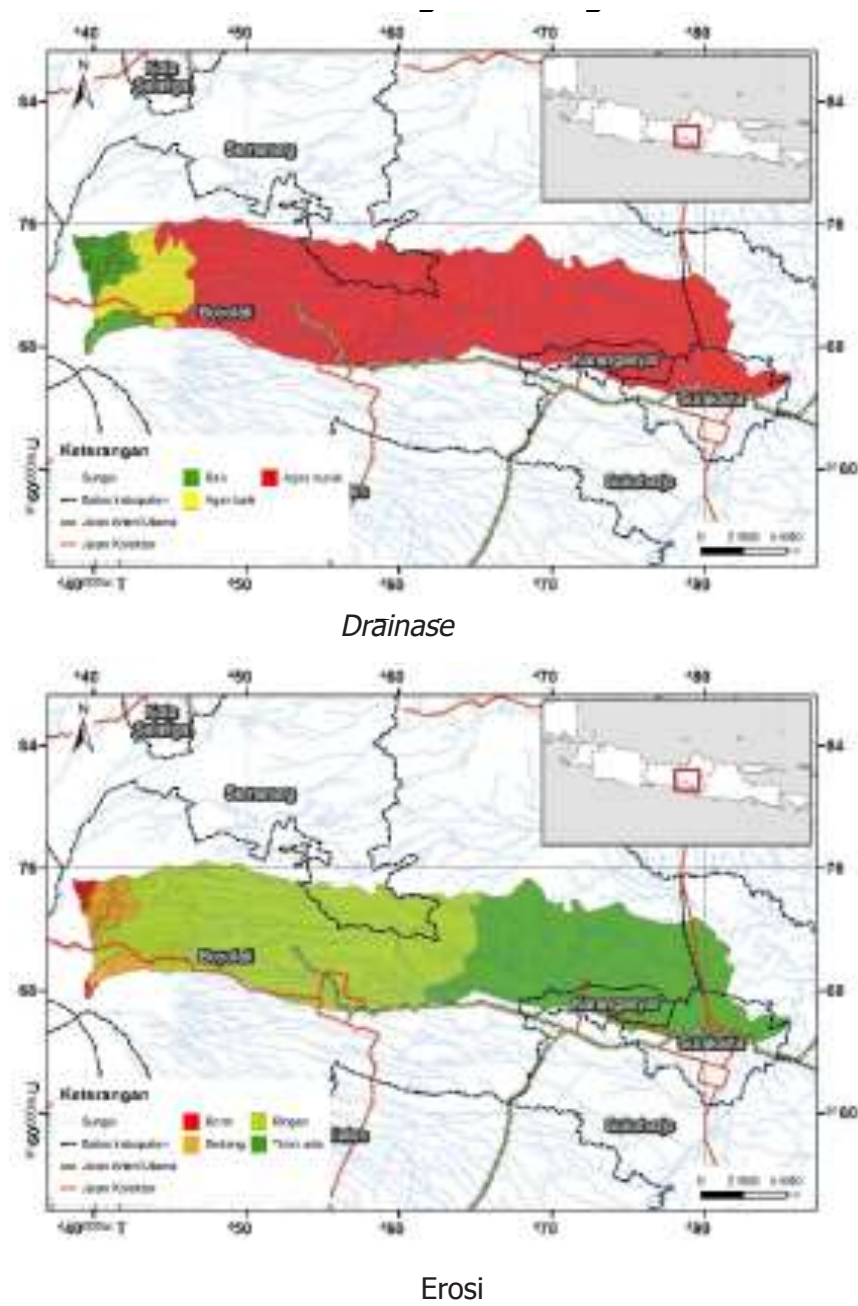

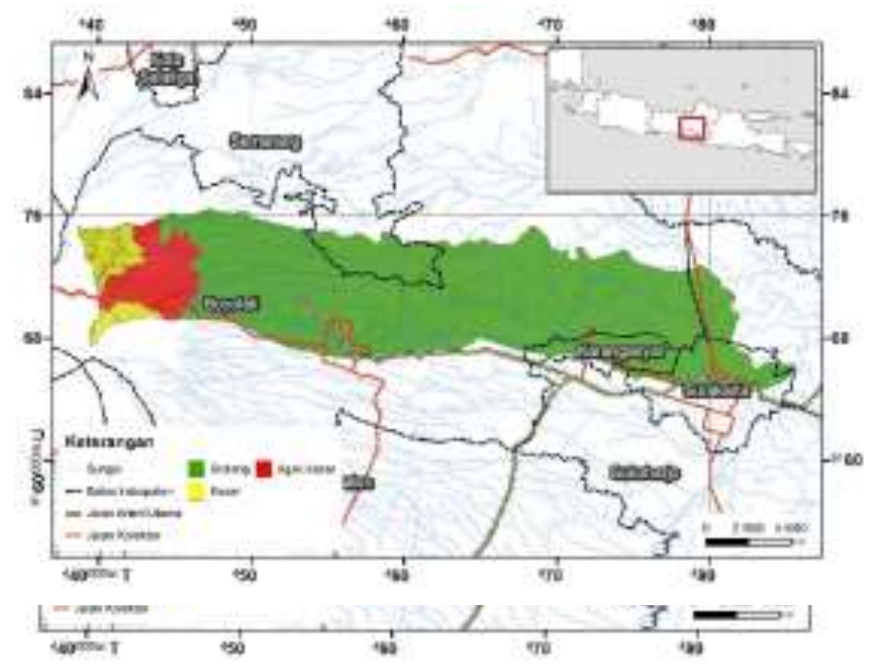

Tekstur tanah
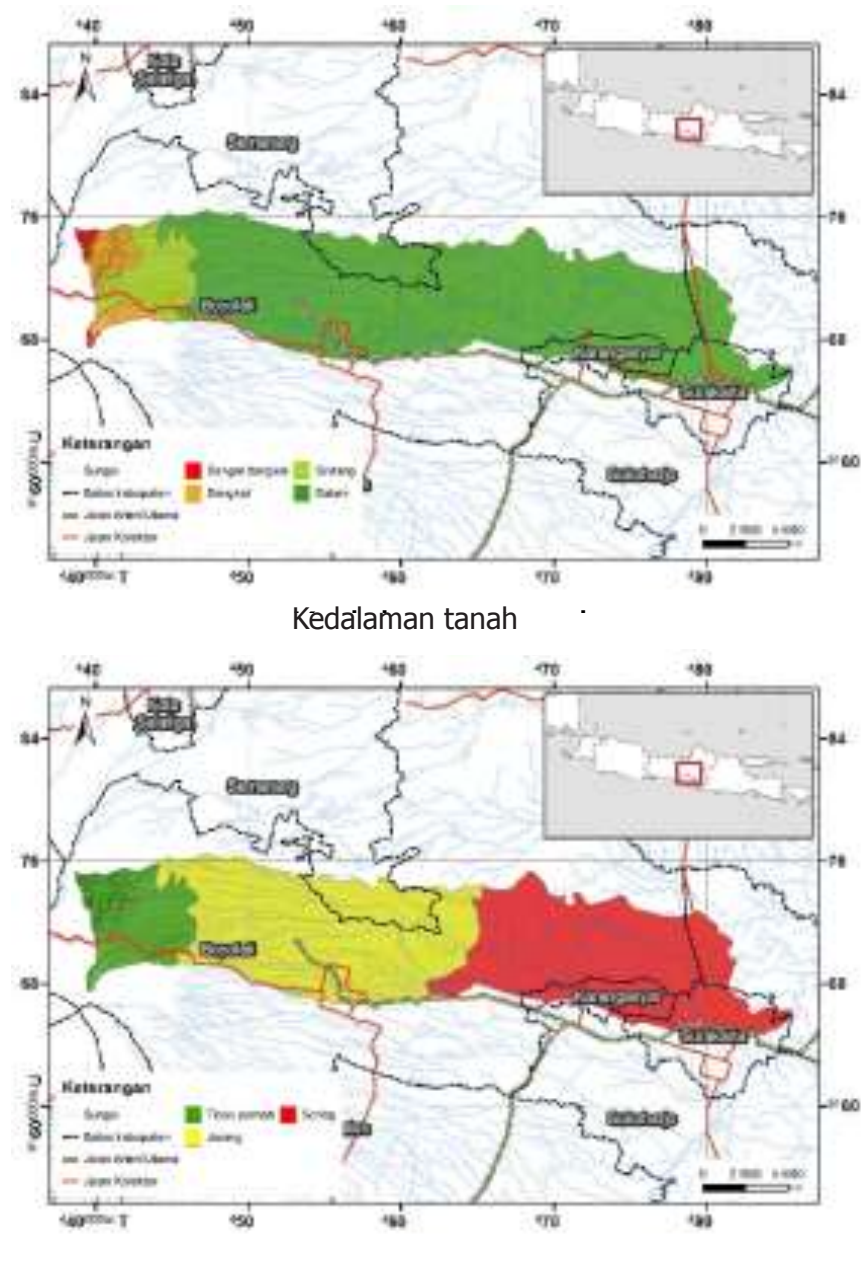

Kerawanan banjir

Gambar 3. Parameter karakteristik wilayah kajian 


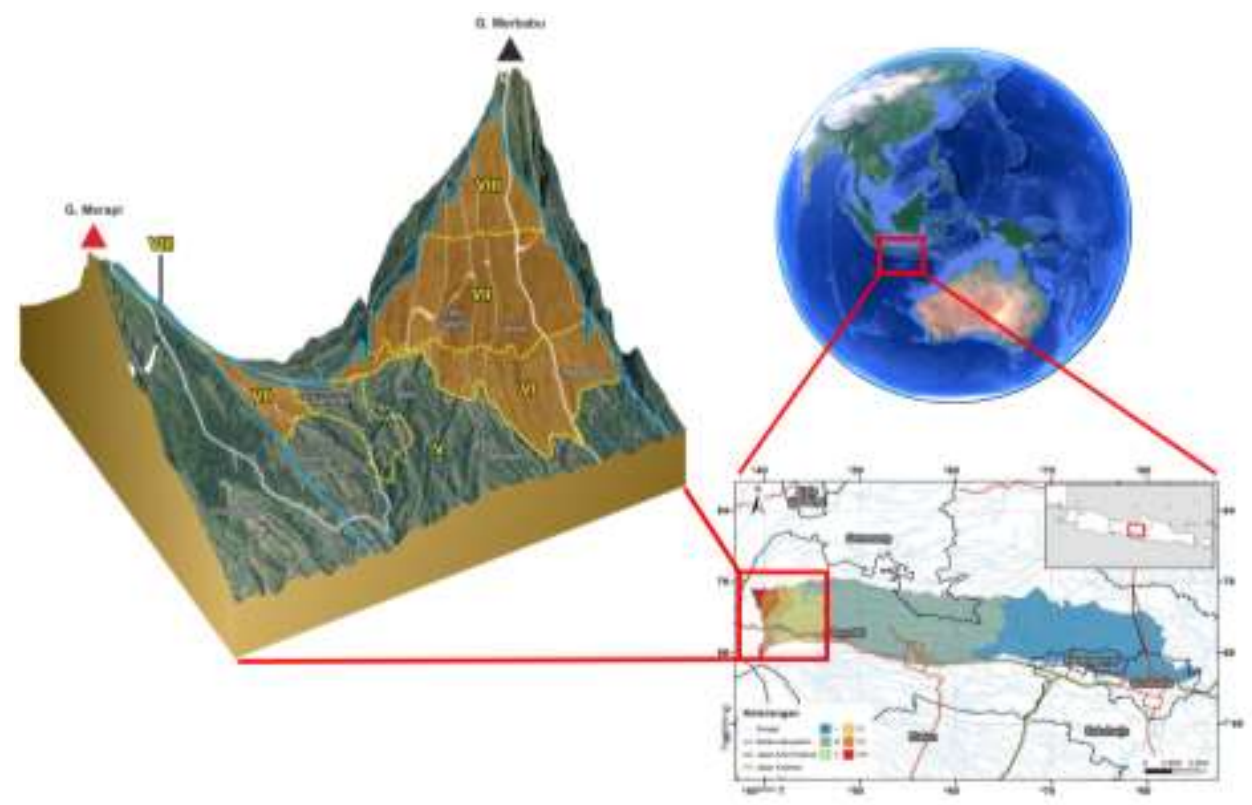

Gambar 4. Wilayah target pembebasan lahan di hulu Sub-DAS Kali Pepe

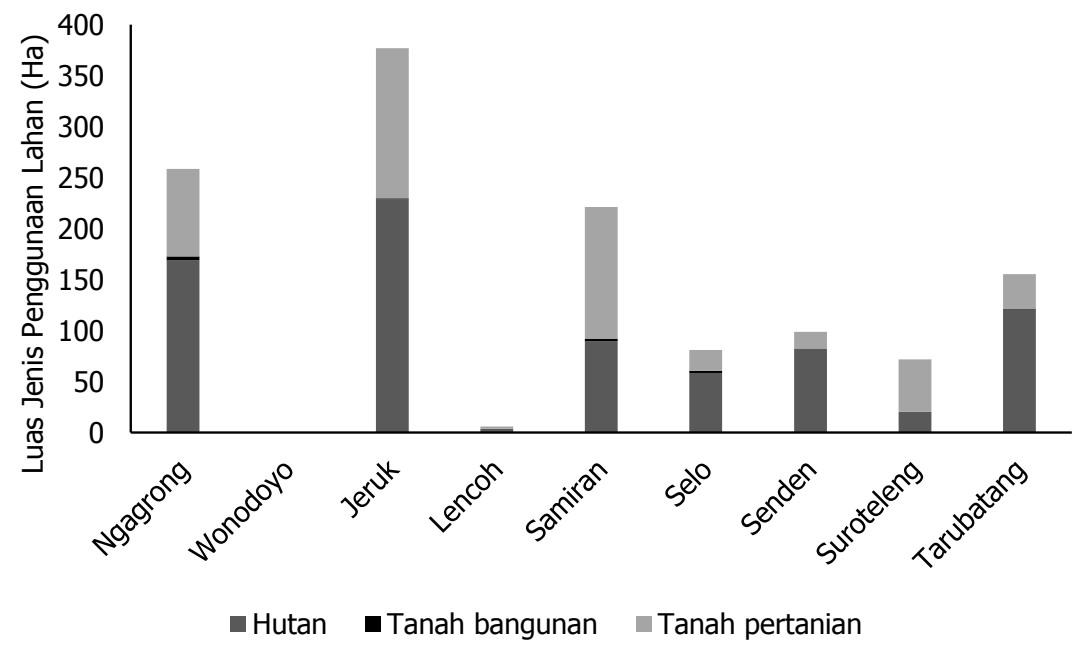

Gambar 5. Luasan Jenis Penggunaan Lahan tiap Desa

penggantian non-fisik meliputi 4 komponen, yaitu solatium, biaya pindah, pajak, dan biaya PPAT. Keempat komponen tersebut menghasilkan nilai total Rp.87,2 miliar seperti yang dirinci pada Tabel 4. Komponen terbesar dari nilai penggantian non-fisik yaitu solatium atau nilai sentimental terhadap rumah tinggal dan diikuti oleh pajak.

Nilai penggantian wajar merupakan penjumlahan antara nilai penggantian fisik dan nilai penggantian non fisik ditambahkan dengan kompensasi masa tunggu yang diasumsikan selama 6 bulan dengan bunga 5,92\% per annum. Hasil dari perhitungan nilai penggantian wajar yaitu sebesar Rp.909,7 miliar seperti yang disajikan secara rinci pada Tabel 5 . Nilai penggantian wajar tersebut terdiri dari $67,6 \%$ nilai penggantian fisik, 9,5\% nilai penggantian non-fisik, dan 22,7\% kompensasi masa tunggu.

\section{Penghitungan Pengurangan Debit Aliran}

Konsekuensi dari perubahan tutupan lahan menyebabkan adanya perubahan debit aliran di SubDAS Kali Pepe. Perubahan debit aliran ini disebabkan akibat interaksi antara komponen tutupan lahan dengan air hujan yang jatuh di wilayah tersebut. Hal ini terkait dengan imbangan hidrologis seperti yang diilustrasikan pada Gambar 6. 
Tabel 3. Nilai penggantian fisik (juta rupiah)

\begin{tabular}{|c|c|c|c|c|c|c|c|}
\hline \multirow{3}{*}{ Desa } & \multicolumn{7}{|c|}{ Penggantian fisik } \\
\hline & \multicolumn{3}{|c|}{ Tanah } & \multirow{2}{*}{ Bgn \& SPL } & \multirow{2}{*}{ Tnm Pertanian } & \multirow{2}{*}{ Tnm Keras } & \multirow{2}{*}{ NPF } \\
\hline & Tanah bangunan & Tanah pertanian & Total & & & & \\
\hline Jeruk & 5.923 & 104.402 & 110.325 & 11.350 & 15.284 & 568 & 137.527 \\
\hline Lencoh & 0 & 1.607 & 1.607 & 0 & 225 & 14 & 1.847 \\
\hline Ngagrong & 4.654 & 60.952 & 65.606 & 46.495 & 5.169 & 414 & 117.684 \\
\hline Samiran & 8.795 & 81.591 & 90.386 & 33.208 & 13.428 & 1.433 & 138.454 \\
\hline Selo & 4.778 & 28.188 & 32.966 & 27.333 & 2.134 & 49 & 62.482 \\
\hline Senden & 0 & 25.178 & 25.178 & 0 & 1.698 & 30 & 26.906 \\
\hline Suroteleng & 439 & 35.566 & 36.005 & 0 & 6.969 & 381 & 43.355 \\
\hline Tr. Batang & 6.959 & 66.761 & 73.720 & 9.608 & 3.598 & 149 & 87.074 \\
\hline Total & 31.548 & 404.246 & 435.794 & 127.993 & 48.504 & 3.037 & 615.328 \\
\hline
\end{tabular}

Besarnya hujan yang jatuh atau komponen presipitasi sama dengan total nilai evaporasi, intersepsi kanopi, intersepsi tumbuhan bawah, infiltrasi, dan direct runoff. Keberadaan hutan menyediakan stratifikasi tajuk dan tumbuhan bawah yang mampu menjadi pengurang jumlah air yang sampai ke permukaan bumi serta yang menjadi direct runoff. Pembebasan lahan dan penghutanan kembali yang dimodelkan pada penelitian

Tabel 4. Nilai pengantian non-fisik (juta rupiah)

\begin{tabular}{crrrrr}
\hline \multirow{2}{*}{ Desa } & \multicolumn{5}{c}{ Penggantian non-fisik } \\
\cline { 2 - 5 } & \multicolumn{2}{c}{ Solatium (30\%) } & \multicolumn{3}{c}{ Transaksi (7,5\%) } \\
\cline { 3 - 6 } & & Biaya pindah (1,5\%) & Pajak (5\%) & Biaya PPAT (1\%) & NPNF \\
\hline Jeruk & 5.182 & 259 & 6.876 & 1.375 & 13.693 \\
Lencoh & 0 & 0 & 92 & 18 & 111 \\
Ngaggrong & 15.345 & 767 & 5.884 & 1.177 & 23.173 \\
Samiran & 12.601 & 630 & 6.923 & 1.385 & 21.538 \\
Selo & 9.633 & 482 & 3.124 & 625 & 13.864 \\
Senden & 0 & 0 & 1.345 & 269 & 1.614 \\
Suroteleng & 132 & 7 & 2.168 & 434 & 2.740 \\
Tr.batang & 4.970 & 248 & 4.354 & 871 & 10.443 \\
\hline Total & 47.862 & 2.393 & 30.766 & 6.153 & 87.175 \\
\hline
\end{tabular}

Tabel 5. Nilai penggantian wajar (juta rupiah)

\begin{tabular}{crrrrr}
\hline Desa & NPF & NPNF & NPF + NPNF & $\begin{array}{r}\text { Kompensasi masa tunggu } \\
(6 \text { bln; 5,92\% pa) }\end{array}$ & Total \\
\hline Jeruk & 137.527 & 13.693 & 151.220 & 44.610 & 195.829 \\
Lencoh & 1.847 & 111 & 1.957 & 577 & 2.535 \\
Ngagrong & 117.684 & 23.173 & 140.857 & 41.553 & 182.410 \\
Samiran & 138.454 & 21.538 & 159.992 & 47.198 & 207.189 \\
Selo & 62.482 & 13.864 & 76.346 & 22.522 & 98.868 \\
Senden & 26.906 & 1.614 & 28.520 & 8.413 & 36.934 \\
Suroteleng & 43.355 & 2.740 & 46.095 & 13.598 & 59.693 \\
Tr.batang & 87.074 & 10.443 & 97.517 & 28.767 & 126.284 \\
\hline Total & 615.328 & 87.175 & 702.504 & 207.239 & 909.742 \\
\hline
\end{tabular}


ini mengasumsikan akan segera terbentuk ekosistem hutan yang memiliki fungsi hidrologis prima sehingga terjadi pengurangan jumlah direct runoff.

Selanjutnya Asdak (2007) menjelaskan konsep koefisien runoff. Koefisien runoff merupakan perbandingan antara hujan yang jatuh dengan besarnya air yang menjadi runoff. Besaran koefisien runoff mulai dari 0 (tidak ada runoff) hingga 1 (seluruhnya menjadi runoff). Nilai koefisien runoff tutupan lahan hutan/ semak belukar, tanah bangunan, dan tanah pertanian berturut-turut sebesar 0,05; 0,25; dan 0,1.

Data intensitas hujan yang digunakan dalam penelitian ini berasal dari data BPS Kabupaten Boyolali. Intensitas hujan di wilayah kajian berkisar antara 0.43 hingga $13.6 \mathrm{~mm} /$ hari. Hasil penghitungan menghasilkan rata-rata intensitas hujan bulanan di wilayah Sub-DAS Kali Pepe yaitu sebesar 5,26 mm/hari.

Berdasarkan seluruh data yang digunakan, debit rasional di Sub-DAS Kali Pepe sebelum dikonversi dan setelah dikonversi menghasilkan debit aliran berturut-turut sebesar 473.433 L/detik dan 334.171 L/detik. Upaya mengurangi debit aliran menggunakan pembebasan lahan dan penghutanan kembali di hulu Sub-DAS Kali Pepe menghasilkan pengurangan debit aliran sebesar 139.263 L/detik atau 29,4\%.

\section{KESIMPULAN}

Luasan wilayah yang dibutuhkan untuk mitigasi banjir Kota Surakarta menggunakan alternatif perolehan lahan di wilayah Hulu Sub-DAS Kali Pepe yaitu seluas $1.269,67 \mathrm{Ha}$ yang melingkup lahan dengan kelas kemampuan VI hingga VIII. Program pembebasan lahan pada wilayah yang ditunjuk membutuhkan biaya yang sangat besar yaitu Rp909.742.252.667,00. Dengan biaya sebesar itu, dapat mengurangi debit aliran $29,4 \%$. Dari hasil penelitian ini maka dapat disimpulkan bahwa alternatif perolehan lahan di wilayah Hulu Sub-DAS Kali Pepe mampu mengurangi debit aliran di Kota Surakarta yang berkontribusi pada Upaya mitigasi banjir Kota Surakarta.

\section{SARAN}

Meskipun cukup banyak mengurangi runoff yang mengalir ke wilayah Kota Surakarta, tetapi masih terdapat beberapa hal yang perlu diperhatikan. Pertama, hal yang dilakukan dalam penelitian ini adalah hanya upaya pengurangan debit aliran yang berasal dari wilayah Hulu Sub-DAS Kali Pepe. Hal ini tidak dapat serta merta menghilangkan banjir di Kota Surakarta melainkan hanya sebagai bagian yang dapat berkontribusi mengurangi besarannya. Kedua, pemindahan masyarakat yang hidup dan memiliki pencaharian di lokasi tersebut dapat menimbulkan dampak sosial. Untuk itu kedepannya perlu dilakukan kajian mengenai dampak sosial sebagai lanjutan dari kajian ini serta perhitungan perubahan debit aliran yang lebih rinci. Penerapan alternatif pemecahan masalah lainnya juga masih sangat memungkinkan sehingga tidak perlu mengeluarkan biaya sebesar yang tercantum serta dampak sosial yang besar pula.

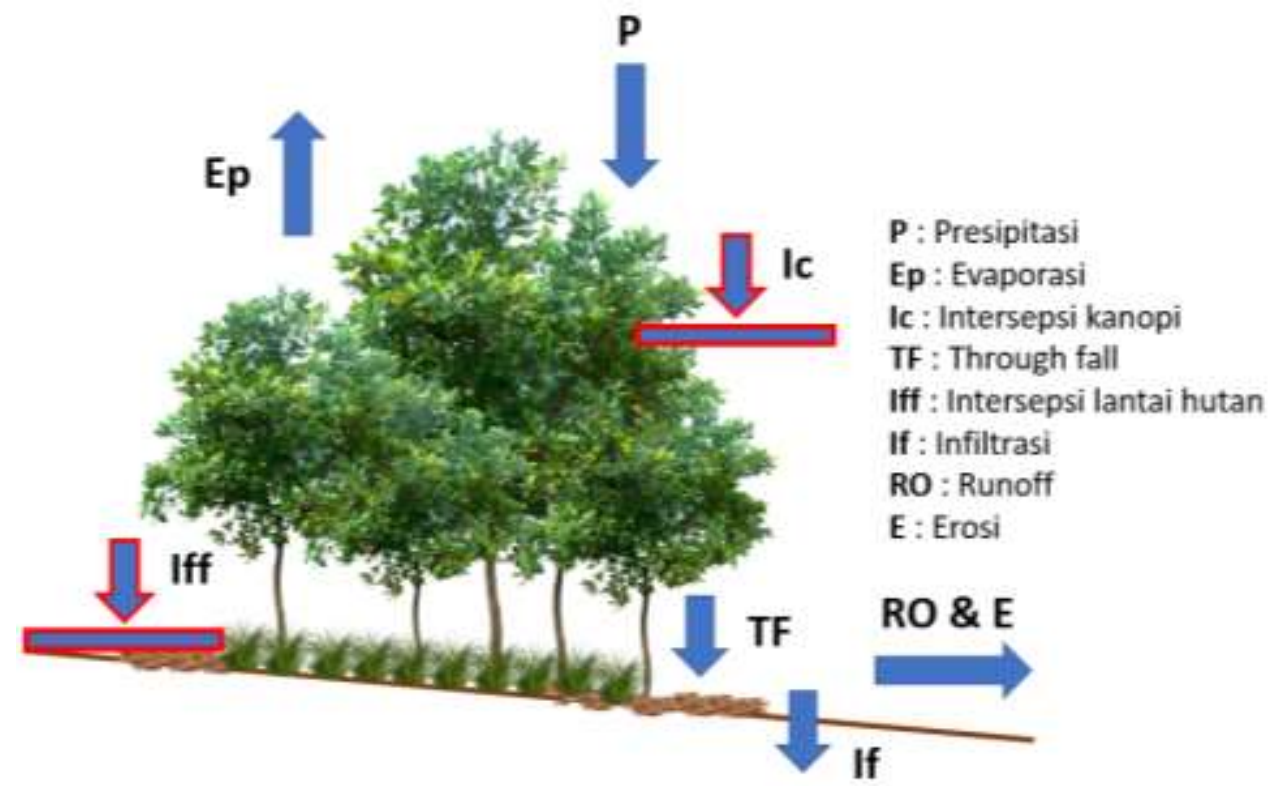

Gambar 6. Imbangan hidrologis pada tutupan lahan hutan 


\section{KONFLIK KEPENTINGAN}

Penulis menyatakan bahwa artikel ini asli hasil penelitian para penulis, hanya dipublikasikan pada jurnal ini, dan tidak ada konflik kepentingan.

\section{DAFTAR PUSTAKA}

Asdak, C. (2007). Hidrologi dan Pengelolaan Daerah Aliran Sungai. Yogyakarta: Gadjah Mada University Press.

Bahinipati, S. B., Rajasekar, U., Acharya, A., \& Patel, M. (2015). Flood-Induced Economic Loss and Damage To The Textile Industry in Surat City, India. London: IIED.

Hardjowigeno, S., \& Widiatmaka. (2007). Evaluasi Kesesuaian Lahan \& Perencanaan Tata Guna Lahan. Yogyakarta: Gadjah Mada University Press.

Irawan, B., \& Paranata, A. (2010). Analisis Penetapan Nilai Ganti Kerugian Properti Korban Luapan Lumpur Lapindo. JEJAK, 3(2), 98-108. DOI: https://doi.org/10.15294/ jejak.v3i2.4653

K.Waghwala, R., \& P.G.Agnihotri. (2019). Flood risk assessment and resilience strategies for flood risk management: A case study of Surat City. International Journal of Disaster Risk Reduction. DOI: https://doi.org/10.1016/j. ijdrr.2019.101155

Komite Penyusunan SPI. (2015). Standar Penilaian Indonesia (Edisi VI-). Jakarta: KPSPI.

KPSPI. (2014). Petunjuk Teknis Penilaian Terhadap Pengadaan Tanah Bagi Pembangunan untuk Kepentingan Umum (SPI 306). Jakarta: Komite Penyusunan Standar Penilaian Indonesia.

Lestari, S. (2002). Analisis Kerugian Banjir dan Biaya Penerapan Teknologi Modifikasi Cuaca Dalam Mengatasi Banjir di DKI Jakarta. Jurnal Sains dan Teknologi Modifikasi Cuaca, 3, 155-159. DOI: http://dx.doi.org/10.29122/ jstmc.v3i2.2174

Li, J., Feng, P., \& Wei, Z. (2013). Incorporating the Data of Different Watersheds to Estimate the Effects of Land Use Change on Flood Peak and Volume Using MultiLinear Regression. Mitigation and Adaptation Strategies for Global Change, 18(8), 1183-1196. DOI: 10.1007/ s11027-012-9416-0
Liu, J., Wang, S. yu, \& Li, D. mei. (2014). The Analysis of the Impact of Land-Use Changes on Flood Exposure of Wuhan in Yangtze River Basin, China. Water Resources Management, 28(9), 2507-2522. DOI: 10.1007/s11269014-0623-1

M.Millerab, M., \& Shirzaeia, M. (2019). Land subsidence in Houston correlated with flooding from Hurricane Harvey. Remote Sensing of Environment, 225, 368-378. DOI: https://doi.org/10.1016/j.rse.2019.03.022

Paul, M. (2016). Impacts of Land Use and Climate Changes on Hydrological Process in South Dakota Watershed. South Dakota State University.

Pilla, F., S.Gharbia, S., \& Lyons, R. (2019). How do households perceive flood-risk? The impact of flooding on the cost of accommodation in Dublin, Ireland. Science of The Total Environment, 650, 144-154. https://doi.org/10.1016/j. scitotenv.2018.08.439

Presiden Republik Indonesia. Undang-Undang No. 5 Tahun 1960 Tentang : Peraturan Dasar Pokok-pokok Agraria (1960). Indonesia.

Presiden Republik Indonesia. Peraturan Presiden Republik Indonesia Nomor 71 Tahun 2012 Tentang Penyelenggaraan Pengadaan Tanah Bagi Pembangunan untuk Kepentingan Umum (2012). Indonesia.

Presiden Republik Indonesia. Undang-Undang No. 2 Tahun 2012 Tentang Pengadaan Tanah Bagi Pembangunan Untuk Kepentingan Umum (2012). Indonesia.

Shi, P., Ma, X., Hou, Y., \& Li, Q. (2013). Effects of LandUse and Climate Change on Hydrological Processes in the Upstream of Huai River, China. Water Resources Management, 27, 1263-1278. DOI: 10.1007/s11269012-0237-4

Zhang, Y., Zhao, Y., Wang, Q., Wang, J., Li, H., Zhai, J., Li, J. (2016). Impact of Land Use on Frequency of Floods in Yongding River Basin, China. Water, 8(9), 401. DOI: 10.3390/w8090401 